\title{
PENGARUH INISIASI MENYUSUI DINI (IMD) TERHADAP REFLEK MENYUSU BAYI BARU LAHIR DAN PRODUKSI ASI IBU POSTPARTUM
}

\author{
Novi Enis Rosuliana ${ }^{1}$, Linda Widiawati ${ }^{2}$, Febriati Astuti ${ }^{3}$ \\ ${ }^{1)}$ Prodi S1 Keperawatan STIKES Mataram, NTB, Indonesia \\ ${ }^{2)}$ Prodi S1 Keperawatan STIKES Mataram, NTB, Indonesia \\ ${ }^{3)}$ Prodi S1 Keperawatan STIKES Mataram, NTB, Indonesia \\ rosuliana_ns_30@yahoo.com
}

\begin{abstract}
ABSTRAK
Pemberian ASI seharusnya dilakukan segera setelah bayi lahir yang dikenal dengan istilah Inisiasi Menyusui Dini (IMD). Pelaksanaan Inisiasi Menyusui Dini (IMD) pada bayi baru lahir meupakan proses keaktifan bayi untuk mencari putting susu ibunya. Isapan bayi baru lahir terhadap putting susu ibu menunjukkan kesiapan reflek bayi untuk menyusu dan memberikan dampak terhadap produksi ASI. Tujuan penelitian ini adalah untuk mengetahui pengaruh Inisiasi Menyusui Dini (IMD) terhadap reflek menyusu bayi baru lahir dan produksi ASI ibu postpartum. Penelitian ini menggunakan cross-sectional design. Subyek penelitian ini adalah semua ibu post partum dengan jumlah sampel 41 responden menggunakan metode accidental sampling. Analisis data dalam penelitian ini menggunakan uji chi square yang menunjukkan bahwa ada pengaruh inisiasi menyusui dini terhadap reflek menyusu pada bayi baru lahir dan produksi ASI ibu postpartum (reflek menyusu $p$ value $0,000<\alpha 0,005$, dan produksi ASI $p$ value $0,002<\alpha 0,005$ ). Hasil tersebut menunjukkan bahwa pelaksanaan inisiasi menyusui dini memberikan pengaruh terhadap reflek menyusu bayi baru lahir dan produksi ASI ibu postpartum. Rekomendasi dari penelitian ini adalah IMD menjadi prosedur yang harus dilaksanakan pada proses persalinan.
\end{abstract}

Kata kunci : Bayi, IMD, ASI, postpartum

\section{PENDAHULUAN}

Pelaksanaan inisiasi menyusui dini (IMD) merupakan proses yang harus segera dilakukan minimal 1 jam setelah bayi lahir. Proses IMD adalah dengan membiarkan bayi secara aktif merangkak di payudara ibu untuk mencari putting susu ibu dan melakukan penghisapan selama 30 menit sampai 1 jam (Roesli, 2012). Bayi baru lahir secara normal akan memiliki refleks mencari dan refleks menghisap untuk mencari putting susu ibu, yang kemudian akan melakukan penghisapan. Hasil penelitian yang dilakukan oleh, Kuswinarno, Syahadatina, Rahmayanti (2013) menunjukkan bahwa terdapat hubungan yang bermakna antara pelaksanaan inisiasi menyusui dini terhadap refleks menyusu pada bayi baru lahir.

Refleks menyusu bayi memberikan suatu stimulus atau rangsangan pada kelenjan pituitary anterior untuk memproduksi lebih banyak hormone prolaktin sehingga kondisi tersebut dapat berdampak pada produksi ASI ibu postpartum. Peningkatan produksi ASI sangat penting dalam memenuhi kebutuhan dan asupan gizi pada bayi serta menunjang sistem imunitas bayi (Sulistyawati, 2009). Hasil penelitian 
yang dilakukan oleh Mandagi, Tandi payung, Rumende (2015) menunjukkan bahwa inisiasi menyusui dini meberikan pengaruh yang signifikan terhadap involusi uterus dan produksi ASI.

Data menunjukkan bahwa lebih dari empat pada setiap sepuluh anak (44\%) disusui dalam satu jam setelah kelahiran dan lebih dari enam diantara sepuluh (62\%) disusui dalam satu hari setelah kelahiran (BPS, 2007). Selain itu cakupan data ASI eksklusif menunjukkan bahwa persentase menyusui eksklusif semakin menurun dengan meningkatnya umur bayi. Pada bayi berumur 5 bulan hanya 15,3\% yang menyusui secara eksklusif, menyusui predominan $1,5 \%$ dan menyusui parsial 83,2\% (Kemenkes RI, 2014).

Hasil studi pendahuluan di Puskesmas Terara setelah bayi lahir, bayi langsung diletakkan di perut ibu pada saat pemotonag tali pusat namun terkadang jarang menunggu sampai bayi menyusu sendiri, Hasil wawancara ibu postpartum didapatkan 3 ibu postpartum pada saat survei pendahuluan didapatkan 2 ibu postpartum dilakukan IMD tetapi tidak sampai bayi menyusu sendiri dan produksi ASInya tidak lancar setelah selesai melahirkan sampai dengan hari ke 2, dan 1 ibu postpartum yang sudah dilakukan IMD sampai bayi menyusu sendiri menunjukkan ASInya lancar. Tujuan dari penelitian ini adalah untuk mengetahui pengaruh pelaksanaan inisiasi menyusui dini (IMD) terhadap reflek menyusu bayi baru lahir dan produksi ASI ibu postpartum.

\section{METODE PENELITIAN}

Desain penelitian yang digunakan dalam penelitian ini adalah pre eksperiment posttest only design. Populasinya adalah semua ibu post partum dengan bayi baru lahir di Puskesmas Terara Lombok Timur dari
Januari-Februari 2017 sejumlah 59 orang.

Sampel dalam penelitian ini sejumlah 41 responden dengan menggunakan teknik accidental sampling berdasarkan waktu. Proses pengumpulan data adalah dengan melakukan observasi pelaksanaan IMD menggunakan instrumen berupa SOP yang tersedia di Puskesmas Terara Lombok Timur, setelah 1 jam dilakukan IMD kemudian mengobservasi refleks menyusu bayi beru lahir dengan menggunakan lembar kuesioner yang terdiri atas 3 pertanyaan, sedangkan untuk observasi produksi ASI dilakukan pada hari ke-2 ibu post partum dengan menggunakan kuesioner produksi ASI yang terdiri atas 8 pertanyaan. Setelah data terkumpul barulah dilakukan analisa data dengan menggunakan uji analisis chi-square untuk melihat ada atau tidak adanya pengaruh IMD terhadap reflek menyusu bayi baru lahir dan produksi ASI ibu postpartum.

\section{HASIL}

Data Umum berupa Karakteristik responden dalam penelitian

Karakteristik responden dalam penelitian ini adalah berdasarkan usia ibu postpartum, paritas, tingkat pendidikan, yaitu :

Tabel 1 Distribusi Responden Berdasarkan Usia

\begin{tabular}{|l|l|l|}
\hline \multicolumn{1}{|c|}{ Umur } & \multicolumn{1}{|c|}{$\begin{array}{c}\text { Frekuensi } \\
(\mathbf{n})\end{array}$} & \multicolumn{1}{c|}{$\begin{array}{c}\text { Persentase } \\
(\%)\end{array}$} \\
\hline$<20$ & 9 & 21,95 \\
\hline $20-35$ & 28 & 68,29 \\
\hline$>35$ & 4 & 9,76 \\
\hline Jumlah & 41 & 100 \\
\hline
\end{tabular}

Tabel 2 Distribusi responden berdasarkan paritas

\begin{tabular}{|l|l|l|}
\hline \multicolumn{1}{|c|}{ Paritas } & \multicolumn{1}{|c|}{$\begin{array}{c}\text { Frekuensi } \\
(\mathbf{n})\end{array}$} & \multicolumn{1}{|c|}{$\begin{array}{c}\text { Persentase } \\
(\boldsymbol{\%})\end{array}$} \\
\hline Primi gravid & 21 & 51,23 \\
\hline Multi gravid & 19 & 46,34 \\
\hline Grande multi & 1 & 2,43 \\
\hline Jumlah & 41 & 100 \\
\hline
\end{tabular}


Tabel 3 Distribusi responden berdasarkan pendidikan

\begin{tabular}{|l|l|l|}
\hline Pendidikan & $\begin{array}{l}\text { Frekuensi } \\
(\mathbf{n})\end{array}$ & $\begin{array}{c}\text { Persentase } \\
(\boldsymbol{\%})\end{array}$ \\
\hline SD & 12 & 29,26 \\
\hline SMP & 8 & 19,52 \\
\hline SMA & 21 & 51,22 \\
\hline Jumlah & 41 & 100 \\
\hline
\end{tabular}

Data Khusus berupa distribusi responden berdasarkan pelaksanaan IMD, reflek menyusu pada bayi baru lahir dan produksi ASI ibu postpartum

Tabel 4 Distribusi Responden

Berdasarkan Pelaksanaan Inisiasi Menyusu Dini

\begin{tabular}{|l|c|c|}
\hline \multicolumn{1}{|c|}{ IMD } & $\begin{array}{c}\text { Frekuensi } \\
(\mathbf{n})\end{array}$ & $\begin{array}{c}\text { Persentasi } \\
(\mathbf{\%})\end{array}$ \\
\hline $\begin{array}{l}\text { Tepat } \\
\text { dilakukan }\end{array}$ & 22 & 53,65 \\
\hline $\begin{array}{l}\text { Tidak tepat } \\
\text { dilakukan }\end{array}$ & 19 & 46,35 \\
\hline Jumlah & 41 & 100 \\
\hline
\end{tabular}

Tabel 5 Distribusi responden berdasarkan refleks menyusu pada bayi baru lahir

\begin{tabular}{|l|c|c|}
\hline $\begin{array}{c}\text { Refleks } \\
\text { menyusu pada } \\
\text { bayi baru } \\
\text { lahir }\end{array}$ & $\begin{array}{c}\text { Frekuensi } \\
(\mathbf{n})\end{array}$ & $\begin{array}{c}\text { Persentasi } \\
(\boldsymbol{\%})\end{array}$ \\
\hline Baik & 29 & 70,74 \\
\hline Tidak baik & 12 & 29,26 \\
\hline Jumlah & 41 & 100 \\
\hline
\end{tabular}

Tabel 6. Tabulasi Silang Pengaruh Inisiasi Menyusui Dini dengan Reflek Menyusu

\begin{tabular}{|l|c|c|c|c|c|c|}
\hline \multirow{2}{*}{ IMD } & \multicolumn{4}{|c|}{$\begin{array}{c}\text { Refleks menyusu pada bayi } \\
\text { baru lahir }\end{array}$} & \multicolumn{2}{c|}{ Total } \\
\cline { 2 - 7 } & \multicolumn{3}{|c|}{ Baik } & \multicolumn{2}{c|}{ Tidak baik } & \multicolumn{2}{c|}{} \\
\cline { 2 - 7 } & $\sum$ & $\%$ & $\sum$ & $\%$ & $\sum$ & $\%$ \\
\hline $\begin{array}{l}\text { Dilakukan } \\
\text { dengan tepat }\end{array}$ & 2 & 100 & 0 & 0 & 2 & 100 \\
\hline $\begin{array}{l}\text { Tidak } \\
\text { dilakukan } \\
\text { dengan tepat }\end{array}$ & 7 & 36,85 & 1 & 63,15 & 1 & 100 \\
\hline & 2 & 70,74 & 1 & 29,26 & 4 & 100 \\
\hline
\end{tabular}

Tabel 7. Distribusi Responden Berdasarkan Produksi ASI Ibu Post Partum

\begin{tabular}{|l|l|l|}
\hline Produksi ASI & $\begin{array}{c}\text { Frekuensi } \\
(\mathbf{n})\end{array}$ & $\begin{array}{c}\text { Persentasi } \\
(\%)\end{array}$ \\
\hline Banyak & 2 & 4,87 \\
\hline Cukup & 25 & 60,98 \\
\hline Sedikit & 14 & 34,15 \\
\hline Jumlah & 41 & 100 \\
\hline
\end{tabular}

Tabel 8 Tabel Silang Pengaruh Inisiasi Menyusui Dini dengan Produksi ASI Ibu Post Partum

\begin{tabular}{|c|c|c|c|c|c|c|c|c|}
\hline \multirow{3}{*}{ IMD } & \multicolumn{6}{|c|}{ Produksi ASI } & \multirow{2}{*}{\multicolumn{2}{|c|}{ Ttotal }} \\
\hline & \multicolumn{2}{|c|}{ Banyak } & \multicolumn{2}{|c|}{ Cukup } & \multicolumn{2}{|c|}{ Sedikit } & & \\
\hline & $\sum$ & $\%$ & $\bar{\sum}$ & $\%$ & $\sum$ & $\%$ & $\sum$ & $\%$ \\
\hline $\begin{array}{l}\text { Dilakukan } \\
\text { dengan tepat }\end{array}$ & 2 & 9,09 & 15 & 68,19 & 5 & 22,72 & 22 & 100 \\
\hline $\begin{array}{l}\text { Tidak tepat } \\
\text { dilakukan }\end{array}$ & 0 & 0 & 10 & 52,63 & 9 & 47,37 & 19 & 100 \\
\hline & 2 & 4.87 & 25 & 60.98 & 14 & 34.15 & 41 & 100 \\
\hline
\end{tabular}

Tabel 9. Hasil analisis IMD dengan Produksi Asi

Chi-Square Tests

\begin{tabular}{|l|r|r|r|}
\hline & \multicolumn{1}{|c|}{ Value } & \multicolumn{1}{c|}{ df } & \multicolumn{1}{c|}{$\begin{array}{c}\text { Asymp. Sig. } \\
\text { (2-sided) }\end{array}$} \\
\hline Pearson Chi-Square & $12.721^{\mathrm{a}}$ & 2 & .002 \\
\hline Likelihood Ratio & 12.977 & 2 & .002 \\
\hline $\begin{array}{l}\text { Linear-by-Linear } \\
\text { Association }\end{array}$ & 11.365 & 1 & .001 \\
\hline N of Valid Cases & 41 & & \\
\hline
\end{tabular}

Tabel 10. Hasil analisis IMD dengan reflek menyusu bayi

Chi-Square Tests

\begin{tabular}{|l|c|c|c|}
\hline & Value & df & $\begin{array}{c}\text { Asymp. Sig. } \\
\text { (2-sided) }\end{array}$ \\
\hline Pearson Chi-Square & $41.000^{\mathrm{a}}$ & 1 & .000 \\
\hline Continuity Correction $^{\mathrm{b}}$ & 36.312 & 1 & .000 \\
\hline Likelihood Ratio $^{\mathrm{F}}$ & 49.572 & 1 & .000 \\
\hline Fisher's Exact Test & & & \\
\hline $\begin{array}{l}\text { Linear-by-Linear } \\
\text { Association }\end{array}$ & 40.000 & 1 & .000 \\
\hline N of Valid Cases $^{\mathrm{b}}$ & 41 & & \\
\hline
\end{tabular}

\section{BAHASAN}

\section{Inisiasi Menyusui Dini}

Pelaksanaan inisiasi menyusu dini dilaksanakan secara tepat sebanyak 22 $(53,65 \%)$, dan pelaksanaan inisiasi menyusu dini secara tidak tepat 
dilakukan sebanyak $19 \quad(46,35 \%)$. Menurut Roesli (2012) menunjukkan bahwa inisiasi menyusui dini dapat dipengaruhi oleh beberapa faktor yaitu keadaan fisik dan psikologis ibu dimana ibu sudah mulai mempersiapkan diri di awal kehamilannya yaitu dengan mencari atau mendapatkan informasi terkait dengan pelaksanaan inisiasi menyusui dini. hal tersebut ditunjukkan bahwa mayoritas tingkat pendidikan responden dalam penelitian ini adalah Sekolah Menengah Atas (SMA).

Tingkat pendidikan SMA merupakan tingkat pendidikan dimana banyak informasi yang diterima dan pola pemikiran lebih berkembang serta inisiatif untuk mencari informasi lebih besar serta sudah mampu melakukan analisa terhadap suatu informasi atau permasalahan. Selain itu usia responden dalam penelitian ini mayoritas adalah usia produktif dan merupakan masuk usia dewasa dimana karakteristik usia dewasa yaitu kemampuan dalam mencari informasi lebih tinggi dan kemampuan berfikir serta memecahkan masalah lebih baik (Wong, 2009).

\section{REFLEK MENYUSU BAYI}

Dari hasil observasi didapatkan hasil penelitian dimana hasil penelitian bayi baru lahir yang melakukan inisiasi menyusu dini secara tepat dengan refleks baik sebanyak 29 (70,74), sedangkan inisiasi menyusu dini yang tidak dilakukan dengan tidak tepat refleksnya tidak baik sebanyak $12(29,26)$.

Segera setelah lahir ,bayi menunjukkan kesiapan untuk mulai menyusu setelah 30-40 menit setelah lahir. Tanda-tanda kesiapan bayi untuk menyusu yaitu mengeluarkan suara kecil, menguap, meregang, adanya pergerakan mulut. Selanjutnya menggerakkan tangan ke mulut, timbul refleks mencari, menggerakkan kepala dan menangis sebagai isyarat menyusu dini. Dengan indra peraba, penghidu, penglihatan, pendengaran, refleks bayi baru lahir bisa menemukan dan menyentuh payudara tanpa bantuan (Roesli, 2008).

Menurut hasil penelitian Dr. Lenard (2009) bayi baru lahir setelah dikeringkan tanpa dibersihkan terlebih dahulu, diletakkan di dekat putting susu ibunya segera setelah lahir, memiliki respon menyusu lebih baik. Apabila dilakukan tindakan terlebih dahulu seperti ditimbang, diukur, atau dimandikan, refleks menyusu akan hilang 50\%, apalagi setelah dilahirkan dilakukan tindakan dan dipisahkan, maka refleks menyusu akan hilang $100 \%$. Bayi yang tidak segera diberi kesempatan untuk menyusu refleksnya akan berkurang dengan cepat dan akan muncul kembali dalam kadar secukupnya dalam 40 jam kemudian. Dengan inisiasi menyusu dini akan mencegah terlewatnya refleks menyusu dan meningkatkan refleks menyusu secara optimal (Kuswinarno, 2013).

\section{PRODUKSI ASI}

Hasil penelitian ini menunjukkan adanya produksi ASI mayoritas dalam kategori cukup. Adapun faktor yang mempengaruhi pengeluaran ASI yang pertama adalah pemberian ASI segera setelah lahir atau inisiasi menyusu dini. Idealnya proses menyusui dapat dilakukan segera setelah bayi lahir, bayi yang cukup bulan akan memiliki naluri untuk menyusu pada ibunya 20-30 menit setelah melahirkan. Ada 2 alesan mengapa menyusui perlu dilakukan sesegera mungkin dalam waktu setengah jam-1 jam setelah persalinan. Yang pertama penghisapan oleh bayi paling kuat dilakukan dalam waktu setengah jam-1 jam setelah lahir. Isapan bayi pada putting akan merangsang hormon 
prolaktin yang merangsang produksi ASI dan hormon oksitosin yang merangsang pengeluaran ASI. Kerja hormon tersebut akan membuat kolostrum lebih cepat keluar. Yang kedua, baik ibu maupun bayi siaga setelah persalinan (Utami, 2013).

Faktor yang mempengaruhi ASI yang kedua adalah umur responden mayoritas adalah usia 20- 35, dimana usia tersebut merupakan usia produktif. Senanda dengan penelitian Kamariyah (2014) yang menyatakan umur 20-35 adalah umur yang pas untuk kesiapan produksi ASInya.

Faktor lainya yang mempengaruhi produksi ASI adalah ketenangan jiwa dan fikiran ibu, perawatan payudara, penggunaan alat kontrasepsi, serta peletakkan putting susu yang tidak tepat (Depkes RI, 2007).

Artinya produksi ASI tidak hanya dipengaruhi oleh inisiasi menyusu dini melainkan ada faktor lain seperti umur responden.

\section{Hubungan inisiasi menyusu dini dengan refleks bayi baru lahir dan produksi ASI}

Setelah dilakukan uji chi square menunjukkan bahwa terdapat pengaruh IMD dengan produksi ASI dengan $p$ value $0,002<\alpha 0,005$, selain itu hasil analisis dengan uji chi square juga didapatkan pengaruh IMD dengan reflek menyusu bayi dengan $\mathrm{p}$ value $0,000<\alpha$ 0,005 . Hal tersebut menunjukkan bahwa Ho ditolak Ha diterima artinya ada pengaruh inisiasi menyusu dini terhadap refleks bayi baru lahir dan produksi ASI.

Mekanisme terjadinya refleks menyusu pada bayi baru lahir dikarenakan bayi baru lahir mempunyai kemampuan indra yang luar biasa, terdiri dari penciuman terhadap bau khas ibunya setelah melahirkan, penglihatan, karena bayi baru mengenal pola hitam putih, bayi akan mengenali putting dan wilayah areola ibunya karna warna gelapnya. Berikutnya adalah indra pengecap meskipun bayi hanya mentolelir rasa manis pada priode segera setelah lahir, bayi mampu mersakan cairan amniotic yang melekat pada jarijari tangannya, sehingga bayi pada saat lahir suka menjilat jarinya sendiri. Indera pendengaran bayi sudah berkembang sejak dalam kandungan, dan suara ibunya adalah suara yang paling dikenalinya. Terakhir indra perasa dengan sentuhan kulit antara bayi dengan ibunya adalah sensasi pertama yang member kehangatan dan rangsangan lainnya.(Eka, 2011).

Mamfaat IMD secara garis besar meliputi beberapa hal berikut seperti meningkatkan refleks menyusu bayi secara optimal. Menyusu pada bayi baru lahir merupakan keterpaduan antara tiga refleks yaitu refleks mencari, refleks menghisap, refleks menelan. Refleks menyusui bayi juga erat kaitannya dengan pengeluaran ASI.

Pengeluaran ASI merupakan suatu interaksi yang sangat kompleks antara rangsangan mekanik, saraf dan bermacam-macam hormone. Rangsangan mekanik terjadi saat bayi menyusu. Gerakan menyedot dan memeras areola dari mulut bayi ini membuat ASI terpancar keluar. Bayi baru lahir memiliki refleks penghisap. Pelepasan ASI berada dibawah kendali neuro endokrin. Rangsangan sentuhan payudara (bayi menghisap) akan merangsang kelenjar pituitary posterior untuk menghasilkan hormone-hormon laktasi. Hisapan bayi memicu pelepasan ASI dari alveolus mammae melalui duktus ke sinus laktiferus. Hisapan juga merangsang produksi hormone prolaktin dan hormone oksitosin (Sulistyawati, 2009)

Peningkatan produksi ASI perlu dilakukan untuk meningkatkan 
keberhasilan menyusu bayi dalam upaya meningkatkan kesehatan bagi bayi dan ibu. Upaya tersebut dapat dilakukan antara lain dengan cara pemberian ASI secara dini atau yang dikenal inisiasi menyusu dini . menyusukan lebih dini akan terjadi perangsangan putting susu, terbentuklah prolaktin oleh hipofisis, sehingga sekresi ASI semakin lancar (Sulistianti, 2016)

Hasil penelitian Wiji (2013), menunjukkan bahwa adanya tindakan IMD oleh bidan pada ibu setelah melahirkan ternyata menunjukkan produksi ASI dengan katagori cukup 27 ibu $(96,4 \%)$. Pada ibu yang melakukan tindakan IMD ternyata semua menunjukkan produksi ASI katagori cukup mencapai $100 \%$. Hal tersebut juga sesuai dengan penelitian Fitria (2010) yang dilakukan pada $7 \mathrm{ibu}$ bersalin yang dilakukan IMD dan 7 tidak dilakukan IMD didapatkan hasil bahwa pada hari kedua terdapat perbedaan produksi ASI pada ibu yang melakukan IMD, yang menyatakan bahwa tidur bayi lebih lama, frekuensi BAB bayi lebih sering, frekuensi BAK bayi lebih sering, frekuensi menyusui lebih sering dan kondisi payudara kosong saat setelah menyusui bayi.

\section{SIMPULAN DAN SARAN}

Pelaksanaan IMD pada responden mayoritas dilaksanakan sesuai dengan SOP (Standar Operasional Prosedur), selain itu setelah dilakukan IMD secara tepat sesuai dengan SOP sebagian besar reflek menyusu bayi baru lahir dalam kategori baik dan produksi ASI rata-rata dalam kategori cukup. Hasil analisa menunjukkan bahwa terdapat pengaruh IMD terhadap reflek menyusu bayi baru lahir dengan produksi ASI ibu postpartum.

Bagi ibu dan bayi baru lahir lebih meningkatkan pengetahuan tentang manfaat IMD terhadap produksi ASI dan reflek bayi baru lahir, bagi profesi keperawatan sebagai bahan referensi dalam proses pengajaran, pengabdian masyarakat dan penelitian, bagi pelayanan kesehatan sebagai bahan refensi penetapan kebijakan dalam penerapan SOP IMD, sedangkan bagi penelitian selanjutnya adalah dengan menggunakan kelompok kontrol dan jumlah sampel lebih banyak.

\section{DAFTAR PUSTAKA}

Badan Pusat Statistik (BPS) dan Macro International. 2007. Survei Demografi dan Kesehatan Indonesia 2007, Calverton, Maryland, USA: BPS dan Macro International.

Depkes RI. (2007). Manajemen Laktasi. Jakarta. Depkes RI

Eka. (2011). Hubungan Antara Inisiasi Menyusu Dini dengan Refleks Menyusu Pada Bayi Baru Lahir. KTI Akademik Kebidanan Mitra Sehat Sidarjo.

Kemenkes RI. 2014. Situasi dan analisis: ASI Eksklusif. Jakarta: Pusat Data dan Informasi Kemenkes RI.

Kuswinarno, V.B., Syahadatina, M., \& Rahmayanti, D. (2013). Inisiasi menyusui dini dengan refleks menyusu pada bayi baru lahir. $D K$ 01 (01). 96-103.

Mandagi, N., Tandipayung, T., \& Rumende, R. (2015). Pengaruh inisiasi menyusui dini terhadap involusi uterus dan produksi ASI ibu post partum di wilayah puskesmas Tinoor. E-Jurnal sariputra, 2(3), 30-36.

Notoatmodjo,S. 2014. Metodologi Penelitian Kesehatan. Jakata : Renika Cipta.

Roesli ,U. 2012. Panduan Inisiasi Menyusui Dini Plus ASI Ekslusif. Jakarta: Pustaka Bunda. 
Sugiyono, 2014. Statistika Penelitian.

Bandung: cv Alfa Beta.

Sulistianti, D.R. 2016. Pelaksanaan

Inisiasi Menyusui Dini (IMD)

dengan Produksi ASI pada Ibu

Postpartum di Rumah Bersalin

Citra Insane Semarang. Jurnal

Studi Univesitas Muhamadiyah

Semarang.

Sulistyawati, A. (2009), Buku Ajar Asuhan Kebidanan Pada Ibu Nifas. Yogyakarta:Andi Offiset

Utami, P.A. 2008. Jurnal Hubungan Inisiasi Menyusui Dini dengan

Wiji, R.N. (2013). ASI dan Panduan Ibu Menyusui. Yogyakarta. 